\title{
大阪湾沿岸部における長周期地震動の地盤増幅特性 および地震波入射方向と上町断層帯の地盤構造の影響
}

\author{
天藤潤一1)、永野正行 ${ }^{2)}$ 、上林宏敏 ${ }^{3)}$ \\ 1) 正会員 東京理科大学大学院、修士課程 \\ e-mail : 7114644@ed.tus.ac.jp \\ 2) 正会員 東京理科大学理工学部建築学科、教授、博士（工学） \\ e-mail : nagano-m@rs.noda.tus.ac.jp \\ 3) 正会員 京都大学原子炉実験所、准教授、博士 (工学) \\ e-mail : uebayash@rri.kyoto-u.ac.jp
}

\begin{abstract}
要 約
2011年東北地方太平洋沖地震本震時に、大阪湾沿岸部において長周期地震動の振幅レベル が急激に増大し、大阪府咲洲庁舎の建物被害に大きな影響を与えた。この地域における波 動伝播及び地盤増幅特性を検証するため、水平 $\mathrm{SH}$ 波入射による地盤応答解析を3次元差分 法により行った。東海・東南海沖を震源と想定した地震波入射方向を考慮したときの地盤 増幅特性を調べるとともに、上町断層帯の深部地盤構造が長周期地震動の増幅に与える影 響を評価した。
\end{abstract}

キーワード：2011年東北地方太平洋沖地震、大阪湾沿岸部、長周期地震動、地盤增幅特 性、3次元差分法、上町断層带

\section{1. はじめに}

2011年東北地方太平洋沖地震時 (以下、3.11本震時と記す) に、大阪湾沿岸部に建つ咲洲庁舎 (B-SKS) にて長周期地震動による国内最大級の建物変位を観測した。これにより、スプリンクラーの破損、エレ ベーターの停止などの建物被害 ${ }^{1)}$ が発生した。さらに、B-SKS とこの地域の強震記録の分析 ${ }^{2) 、 3)}$ から、大 阪湾沿岸部で周期6 8秒の成分が増大したことは明確である。後藤・永野 $(2013)^{4}$ や酒井・宮本 $(2013)^{5}$ は 震源から大阪平野にかけて地盤をモデル化し再現解析を行ったが、3.11本震時の定量的な観測記録の再 現には至っていない。想定東海・東南海連動地震のシミュレーション解析においては、紀伊半島沖の付 加体の有無が波動伝播や地盤応答に影響を及ぼすの)、7) とされ、吉村・山本 $(2008)^{8}$ は南海トラフ地震発生 時において、大阪湾沿岸部の此花(OSKH02)における周期7秒の成分が卓越し、周期4秒以上において告示 スペクトルを大きく上回る地盤応答が発生し得ると示している。東海・東南海沖を震源と想定した海溝 型巨大地震に備え、今後の地震動予測やBCP（事業継続計画）の観点から、同地域内の急激な地盤増幅 に対する原因の究明、及びその影響による建物変位の増幅に関する対策が早急の課題である。

そこで本稿では、大阪平野を含む地盤領域のみを対象に地盤をモデル化し、水平SH波入射により 3.11 本震時における観測波の再現を試み、波動伝播特性及び地盤増幅特性を評価する。また、東海・東南海 沖地震の発生を想定し、地震波の入射方向を変化させた時の地盤増幅特性を調べるとともに、上町断層 帯、及びその周辺の深部地盤構造が大阪湾沿岸部の地盤増幅と伝播特性に与える影響について検討寸る。 


\section{3. 11本震時における観測波の再現と地盤応答評価}

\subsection{3次元地盤モデルと解析条件}

図1中の各観測点における地盤応答を3次元差分法によって解析する。対象の観測点は、B-SKSを通る $\mathrm{N} 235^{\circ} \mathrm{E}$ の測線(図1中の赤破線)付近の、3.11本震時に観測記録を良好に得られた地点とした。対象領域 内の地盤増幅特性を把握するため、基盤深度が急激に深くなる上町断層帯西側のFKS、RC-M等、上町 断層帯東側のMRG、OSK004等の観測地点を採用した。なお、上町断層帯東側において生駒断層帯付近 のTTT及びMRGは上町断層帯上盤側の台地部に位置するEBCに比べやや基盤深度が深くなっている。

天藤・永野 $(2013)^{9)}$ による震央から大阪平野一の地震波入射方向（約 $N 235^{\circ} \mathrm{E} ）$ を考慮し、大阪平野堆 積層の外側をすべて基盤とした3次元地盤モデルを構成した。本稿での地盤モデルは天藤・永野(2013) に対し、図1に示す大阪平野の堆積層領域でトリミングし、その周辺全てを基盤とした。

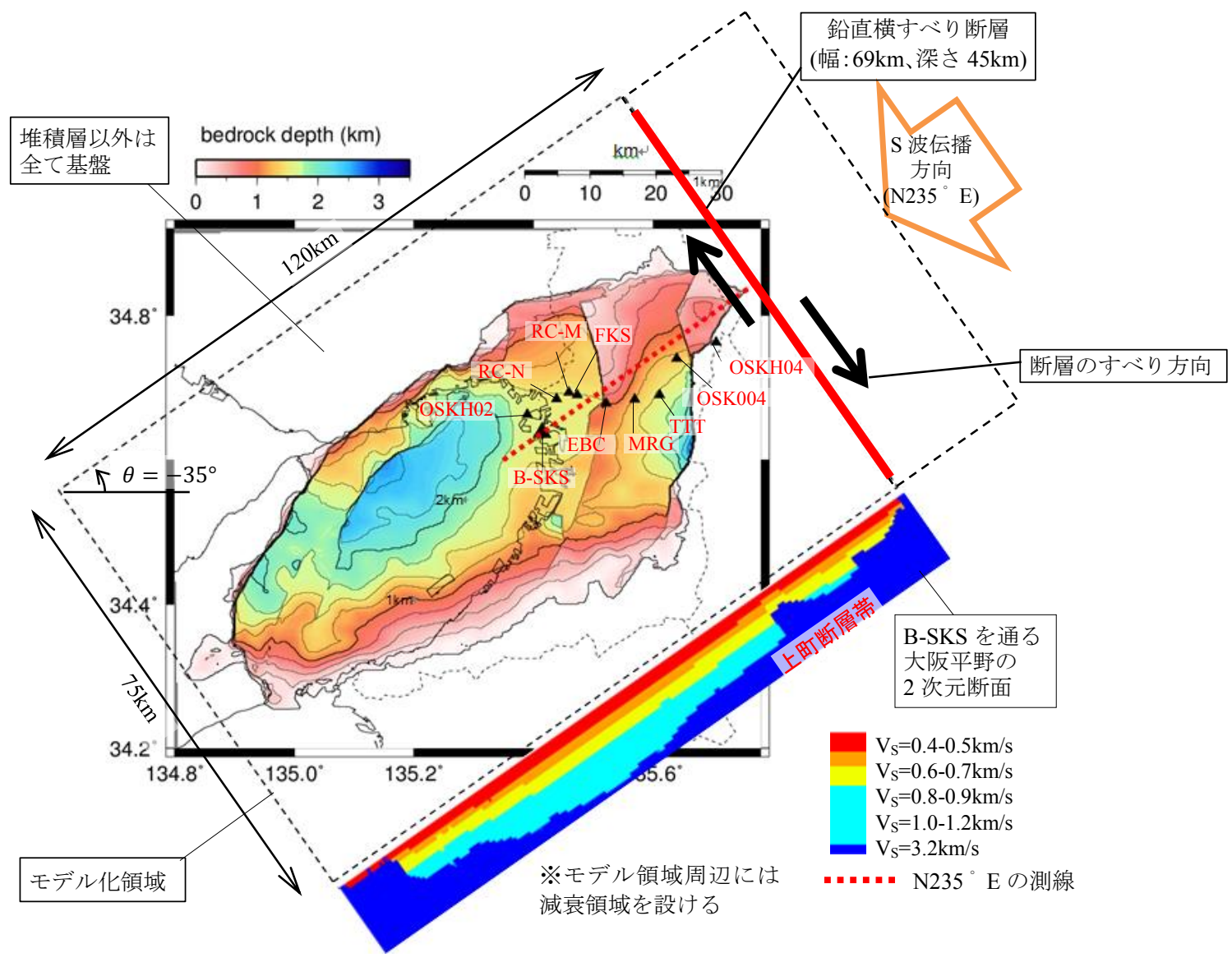

図 1 モデル化領域と B-SKS を通る 2 次元断面

堆積層領域におけるグリッド間隔は水平方向を $0.15 \mathrm{~km}$ 、深さ方向を $0.1 \mathrm{~km}$ とした。構築する地盤構造 は大阪府 $(2006)^{10)}$ によって作成された 3 次元速度構造モデルを参照した。今回と大阪府のモデルのグリ ッドが平行ではないため、両モデルの格子点が一致しない。そこで、モデル格子点のリサンプリング を行い、それら格子点における物性值は、対応する大阪府のモデルの周辺8ポイントから内挿した。解 析には浅部領域と深部領域でグリッド間隔を変化させた3次元差分法を用いた ${ }^{11)}$ 。モデル化領域は反時 計方向に $35^{\circ}$ 回転させ短辺方向 $75 \mathrm{~km}$ 、長辺方向 $120 \mathrm{~km}$ 、鉛直方向 $3 \mathrm{~km}$ とする。対象とする地盤は $\mathrm{Vs}=0.4 \sim 1.2 \mathrm{~km} / \mathrm{s}$ とし、 $\mathrm{Vs}=3.2 \mathrm{~km} / \mathrm{s}$ の層を基盤とした。各地層における物性值を表 1 に示寸。長周期地震 動予測地図 $(2012)^{12)}$ の地盤構造モデルを参考に、Q值はVs $(\mathrm{m} / \mathrm{s}) / 5$ とし、その参照周期は2秒とした。モデ ル右側に浅部領域と深部領域にまたがる幅 $69 \mathrm{~km}$ 、深さ $45 \mathrm{~km}$ の鉛直断層を設定した。断層は一様に横す べりさせ、SH波の水平入射を模擬した。再現解析を行うにあたり、周期 2 秒以上の周期で十分な振幅を 確保できるように、入射波として中心周期 3 秒と 6 秒のRicker波を混在させた波を用いる。モデルの外側 には人工的な波動の反射を防ぐため減衰領域を設けた。対象周期は2秒以上とする。 
表1 各地層の物性値

\begin{tabular}{|c|c|c|c|}
\hline 層No. & $\mathrm{Vs}(\mathrm{km} / \mathrm{s})$ & ポアソン比 $v$ & 密度 $\rho\left(\mathrm{t} / \mathrm{m}^{3}\right)$ \\
\hline 堆積層1 & 0.4 & 0.468 & 1.77 \\
\hline 堆積層2 & 0.5 & 0.458 & 1.94 \\
\hline 堆積層3 & 0.6 & 0.445 & 2.00 \\
\hline 堆積層4 & 0.7 & 0.431 & 2.00 \\
\hline 堆積層5 & 0.8 & 0.417 & 2.04 \\
\hline 堆積層6 & 0.9 & 0.408 & 2.06 \\
\hline 堆積層7 & 1.0 & 0.398 & 2.15 \\
\hline 堆積層 8 & 1.1 & 0.390 & 2.19 \\
\hline 堆積層9 & 1.2 & 0.382 & 2.20 \\
\hline 基盤 & 3.2 & 0.229 & 2.66 \\
\hline
\end{tabular}

\subsection{3次元解析による観測波の再現}

水平 $\mathrm{SH}$ 波入射時の各観測点における応答波形から、各観測地点の $\mathrm{TTT}\left(\mathrm{N} 325^{\circ} \mathrm{E}\right)$ に対する伝達関数を フーリエスペクトル比より求め、図 2 中のTTTの観測記録 $\left(\mathrm{N} 325^{\circ} \mathrm{E}\right)$ を地点毎の伝達関数にかけ、評価地 点の応答波形を求めた。天藤・永野(2013)では、観測記録にかけるバンドパスフィルターを $0.1 \sim 0.4 \mathrm{~Hz}$ としたが、本検討ではモデルの対象周期に合わせ $0.1 \sim 0.5 \mathrm{~Hz}$ とした。各観測点の $325^{\circ} \mathrm{E}$ における時刻歴 波形を図2(a)、擬似速度応答スペクトル $\mathrm{pSv}(\mathrm{h}=5 \%)$ を図 $2(\mathrm{~b})$ に示寸。観測記録と解析結果ともに、岩盤 地点であるOSKH04では振幅が小さく、生駒断層を超えて地震動の振幅が大きくなる。上町断層帯の手 前のEBCで一度地震動が小さくなるが、上町断層帯を超えて再び大きくなる。大阪湾沿岸部である B-SKSでは、長周期成分が増幅し、卓越周期が7秒に長くなる傾向が再現された。天藤・永野(2013) と は、フィルターやモデルの違いにより、結果の数值が若干異なるが、波形の概形はほぼ整合している。

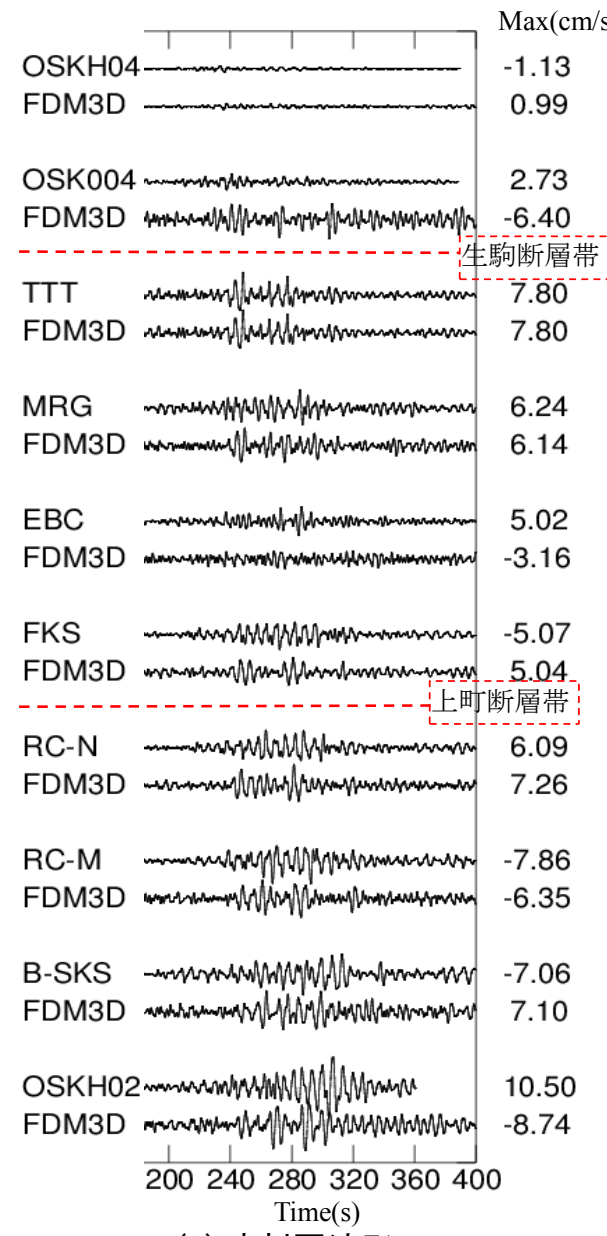

(a) 時刻歴波形
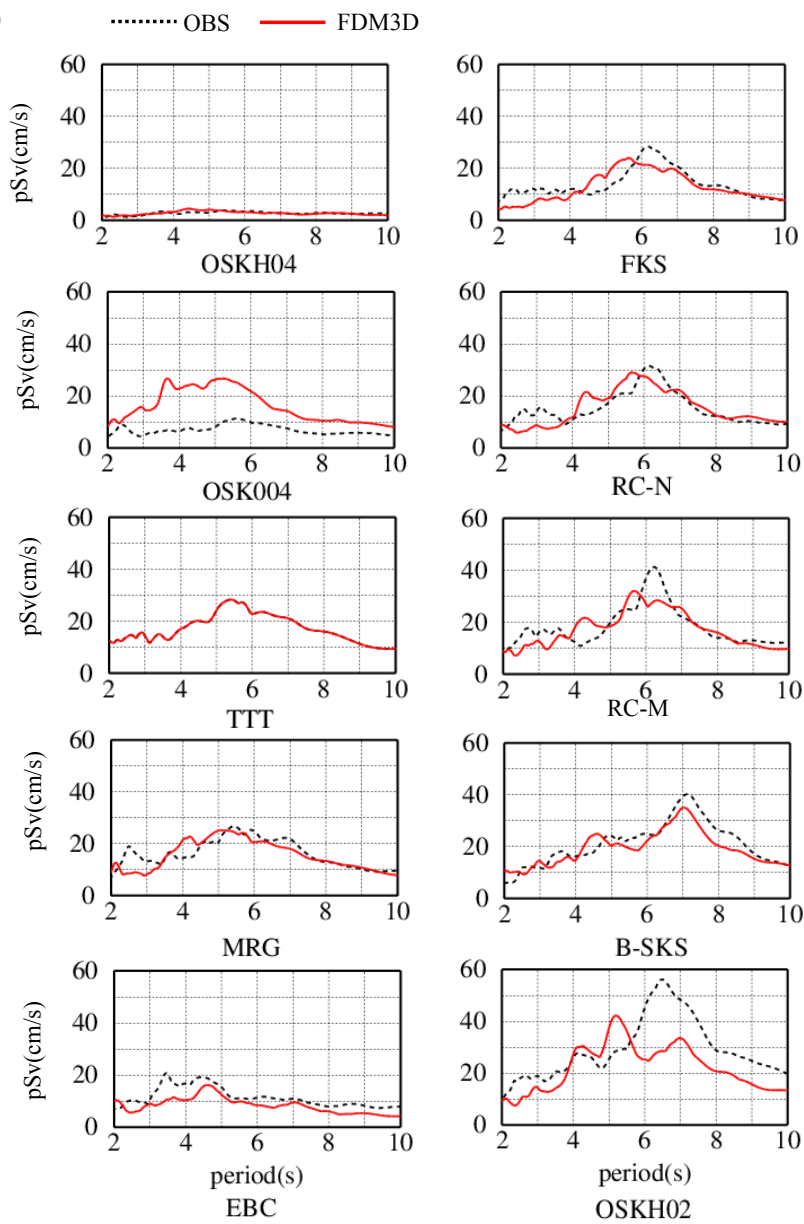

(b) 擬似速度応答スペクトル pSv $(h=5 \%)$

図2 3次元解析結果と観測記録の比較 $\left(\mathrm{N} 325^{\circ} \mathrm{E}\right)$ 
OSKH02 とB-SKSの入射S波に対する伝達関数を図3に示す。B-SKSに比べOSKH02の0.16Hzの成分が 減少し、0.2Hz成分が増大したことが確認できる。この傾向は、図2(b)におけるOSKH02の解析結果によ るpSv と同様である。図2のOSKH02において、他地点に比べ観測記録の再現性が劣る原因は、3次元地 形効果により大阪湾沿岸部で長周期地震動の空間変動が大きくなったものと推測される。

ここで、図4に、3.11本震時における大阪堆積層に到来する地震波のスナップショット ${ }^{4}$ を示す。 2.1 節では、地震波到来直後の図4(a)の入射方向を用いたが、後続の波形において入射角がわずかに変化し、 図4(b)においては $30^{\circ}$ 程度となった。図1に示す $\theta$ を- $30^{\circ}$ (以下ANG-30) とし、大阪堆積層がモデル領域内 に収まるよう調整した。さらに断層についても同様に回転させた上で再現解析を行った。解析手法等 の諸条件は本節冒頭と同様とする。ANG-30の時のB-SKS及びOSKH02の時刻歴速度波形と擬似速度応 答スペクトル $\mathrm{pSv}(\mathrm{h}=5 \%)$ を図 5 に示す。従来の結果に比べ、OSKH02において、波形の概形がより観測記 録に整合する傾向にある。一方でB-SKSは、卓越周期は一致するが、観測記録に比べ過大評価となった。 これらの傾向から、空間変動の大きい領域では、入射方向の僅かな変化によって地盤応答特性及び観 測記録の再現性に影響を与えることが検証された。

以上の結果から、本検討では簡単な入射場を仮定したが、OSKH02における観測記録をより良好に再 現するためには，より現実的な入射場を設定する必要があるといえる。しかしながら、B-SKSでの地震 動増幅の傾向が概敉再現されていること、本研究の目的が大阪湾沿岸部での地盤増幅入カニズムを把 握することであることから、以降では2.1節で述べた従来のモデルを用いて、B-SKSに着目した地盤増 幅特性の詳細検討を行う。

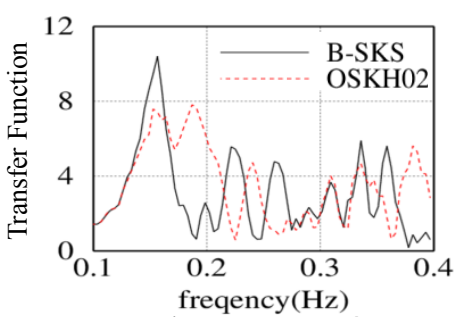

図 3 各地点の伝達関数

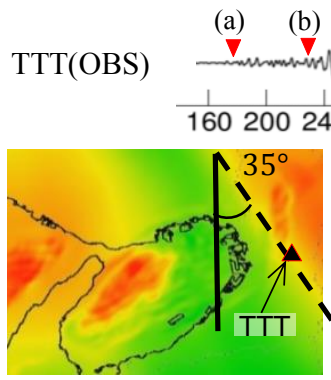

(a) $\mathrm{t}=178 \mathrm{~s}$ (b)

plow
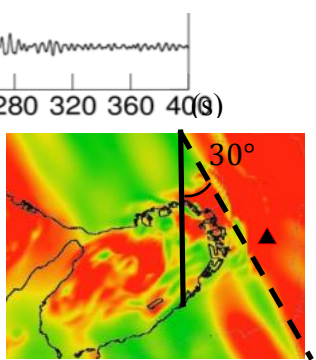

(b) $\mathrm{t}=230 \mathrm{~s}$

図4３.11本震時の地震波の到来方向の推移 ${ }^{4}$

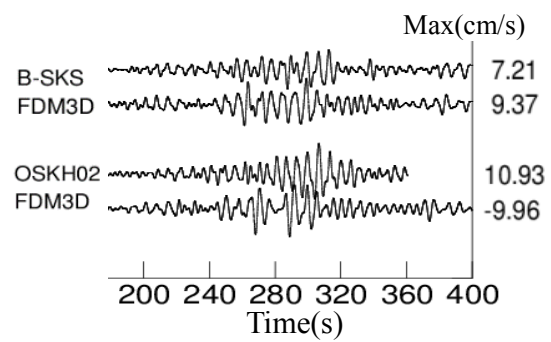

(a) 時刻歴波形

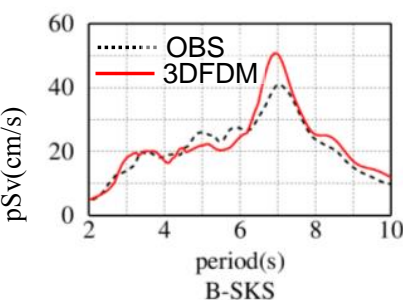

(b) 擬似速度応答スペクトル pSv $(\mathrm{h}=5 \%)$

図 5 ANG-30 の各評価地点における 観測記録と解析結果の比較

\subsection{3次元地形効果が地盤増幅に与える影響}

大阪平野の3次元地盤モデルの基本的な地盤増幅特性を把握するため、中心周期6秒のRicker波を最大 振幅1の速度波形として入射した時の、図6に示寸岩盤側からB-SKSを通るN $235^{\circ} \mathrm{E} の$ 測線上における $4 \mathrm{~km}$ ごとの地点P01 B-SKSを対象に、地盤応答を算定する。各地点における時刻歴速度波形を図7(a)に 示す。生駒断層帯で表面波が励起され、堆積層内で振幅レベルが増大する。上町断層帯手前で一度振 幅は減少するが、上町断層帯より沿岸部側の地点にて再度増大寸る。岩盤側から遠方になるにつれ継 続時間が長くなる傾向にある。

大阪平野内における3次元地形効果の影響を検証するため、B-SKSを通り S波入射方向の直線上の 2 次 元地盤構造を投影して3次元モデルを作成し、同様の計算をおこなった。2次元地盤モデルの応答を図 7(b)に示す。B-SKSなどの大阪湾沿岸部の地点では、2次元解析に比べ3次元解析は後続の表面波が増幅 寸る傾向にある。図8に3次元解析によって得られたRicker波入射時のスナップショットを示す。 $\mathrm{t}=21.2 \mathrm{~s}$ のB-SKSでは振幅コンターが縞状となっており、2次元的に波動が伝播する形となっている。一方、図 8 中の $\mathrm{t}=34.8 \mathrm{~s}$ ※印では、振幅コンターが点状となっている。これは図7中の※印に対応するものであり、 堆積層内で後続波が3次元地形効果によってB-SKS付近に集中したものと判断できる。 
以上の結果から、3.11本震時の大阪湾沿岸部における長周期地震動による地盤増幅は、堆積層内で励 起された表面波が3次元地形効果によって干渉し、生じたものと推察される。

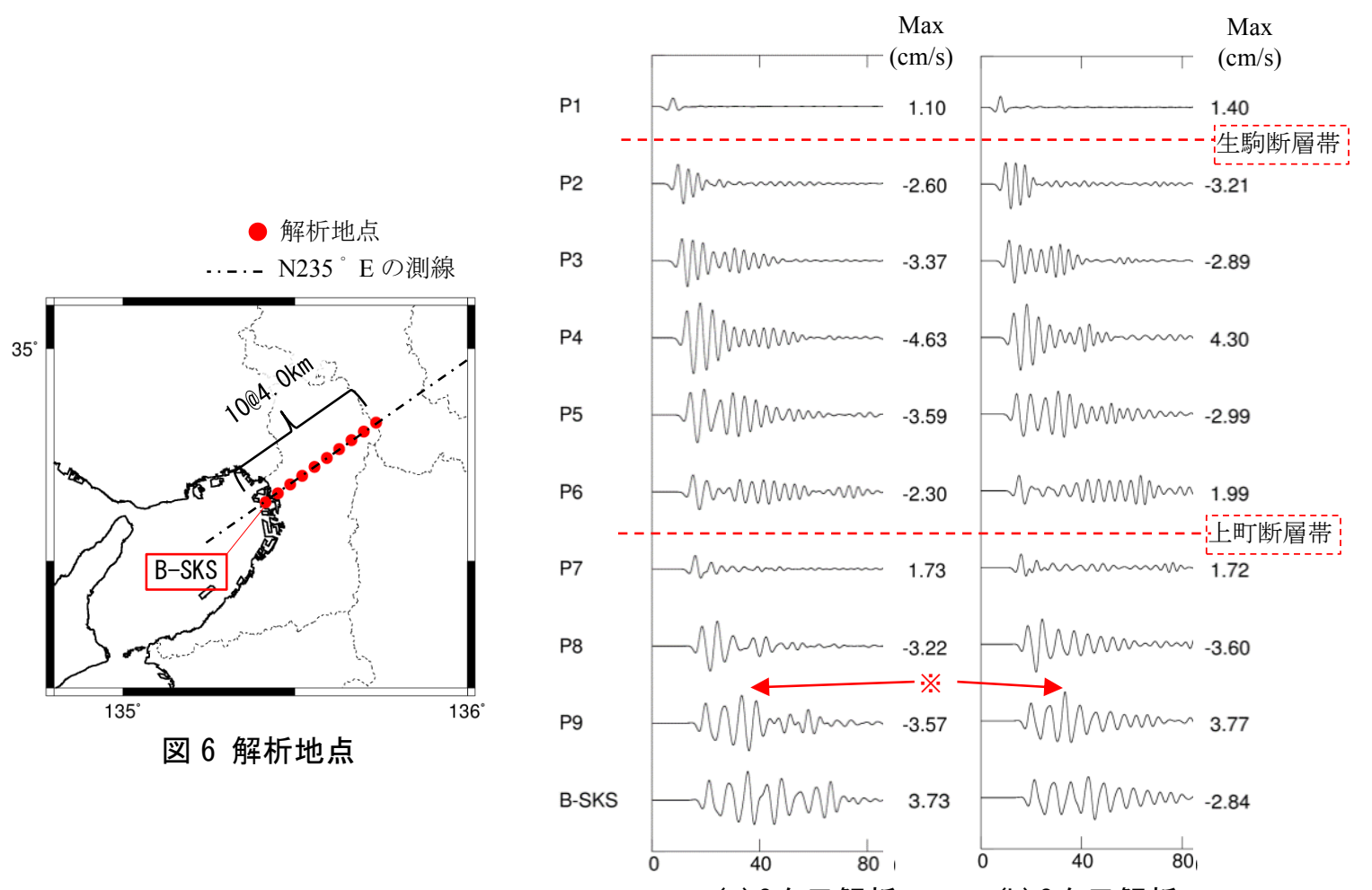

$\begin{array}{ll}\text { (a) 3次元解析 } & \text { (b) 2次元解析 }\end{array}$

図7 中心周期6秒のRicker 波入射時の2次元解析と3次元 解析の時刻歴波形の比較

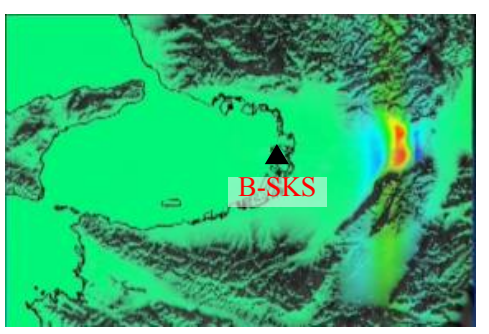

$\mathrm{t}=10.8 \mathrm{~s}$

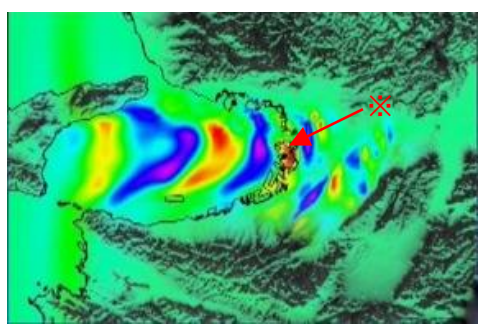

$\mathrm{t}=34.8 \mathrm{~s}$

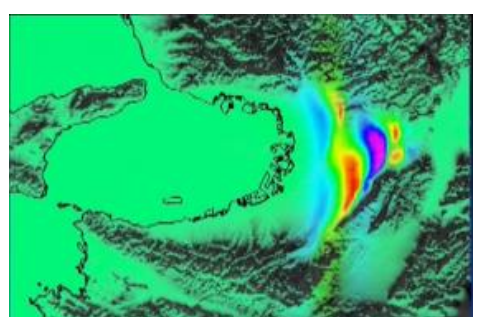

$\mathrm{t}=16.2 \mathrm{~s}$

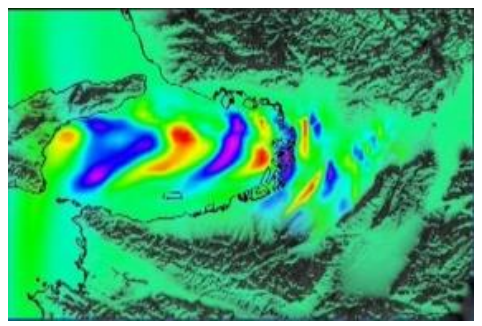

$\mathrm{t}=37.8 \mathrm{~s}$

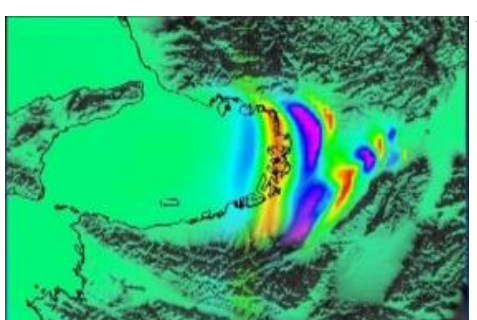

$\mathrm{t}=21.2 \mathrm{~s}$

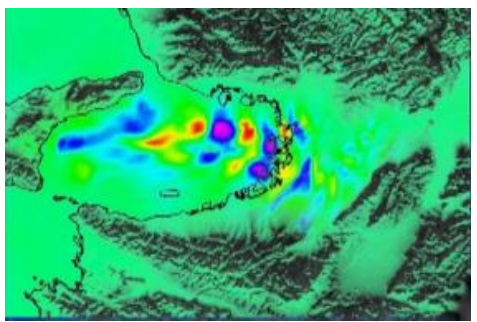

$\mathrm{t}=48.8 \mathrm{~s}$

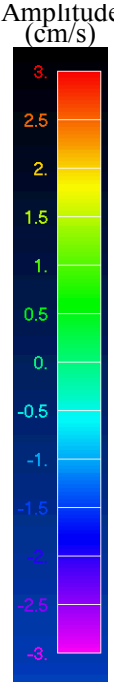

図8 中心周期6秒のRicker波入射時の波動伝播の様子 


\section{3. 地震波入射方向が地盤増幅に与える影響}

大阪平野内の地震波入射方向の差異が地盤増幅にもたらす影響を把握するため、南海トラフで地震 が発生した時の状況を想定し、B-SKSにおける地盤応答及び波動伝播特性について評価する。中央防災 会議 ${ }^{13)}$ によって公表された南海トラフ地震発生時の予測強震動生成領域を参考に、図9(a)に示す $\mathrm{S}$ 波入 射方向を設定した。B-SKSを原点におき、時計方向を正にしたとき、3.11本震時の入射方向を $-35^{\circ}$ 、南 海トラフ地震時の方向を $0^{\circ} 、 30^{\circ} 、 60^{\circ} 、 90^{\circ}$ にそれぞれ設定した。地盤モデルは、モデル化領域を地震 波の入射角によって図 1 に示寸 $\theta$ を $0^{\circ} 、 30^{\circ} 、 60^{\circ} 、 90^{\circ}$ にそれぞれ変更し、2.2節と同様にモデル化領域を 調節後、断層を構築した。その他地盤モデルに関する諸条件、解析手法及び入射する地震波は、従来 のモデルと比較検討を行うため2章と同様とし、2次元及び3次元モデルについて検討を行う。

中心周期6秒のRicker波を水平入射した時のB-SKSにおける各入射方向の 3 次元及び 2 次元解析の時刻 歴波形を図9(b)に示寸。いずれの入射方向においても、前章同様に2次元解析に比べ3次元解析の後続波 が増幅傾向にあり、3次元地形効果による表面波の干渉が確認できる。摇れ始めから約30秒は各入射方 向の波形はほぼ同一であるが、後続の波形で各入射方向により差が生じ、ANG30が最も振幅レベルが 大きくなる。ANG-35については、他の入射方向に比べ後続波の影響が小さくなり、振幅が減少傾向に ある。B-SKSにおけるフーリエ振幅スペクトルを図 $9(\mathrm{c})$ に示す。 $0.16 \mathrm{~Hz}$ の成分において各入射方向に顕 著な差はないが、0.18 0.22Hzの成分において、ANG-35が比較的小さくなる。ここで、図7(a)に示す各 入射方向の測線上における2次元地盤断面略図を図10に示す。

以上の結果から、震源域を東海・東南海沖に想定した場合、上町断層帯の基盤段差による影響を受 けず、後続波の振幅レベルが増加傾向になることから、大阪湾沿岸部の長周期地震動による地盤増幅 は、3.11本震時に比べ大きくなる可能性がある。また、増幅する周期帯が広がることから、より多くの 建物に長周期地震動による建物被害が及ぶ懸念がある。また、ANG-35における後続波と0.18 0.22 Hz の成分の減少傾向が対応することから、堆積盆地内における波動伝播経路上の基盤形状が、増幅する 周期帯の傾向にも影響を及ぼすと評価できる。

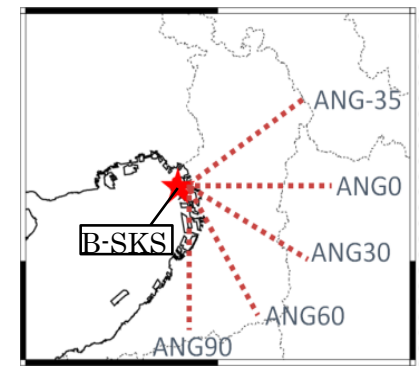

(a) $S$ 波入射方向

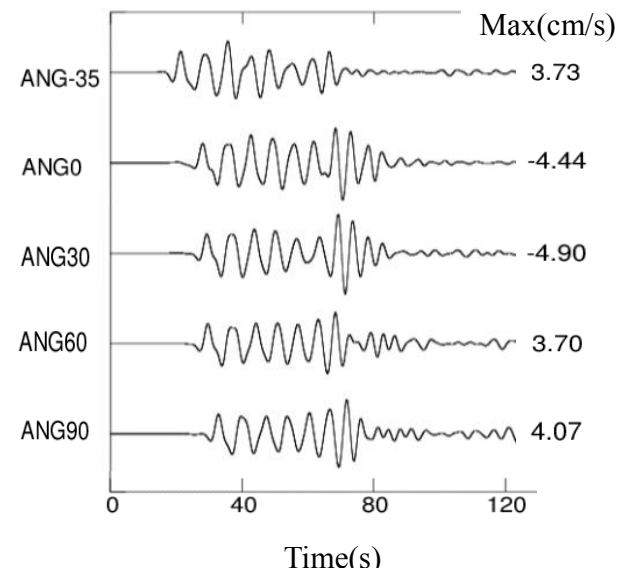

3 次元解析

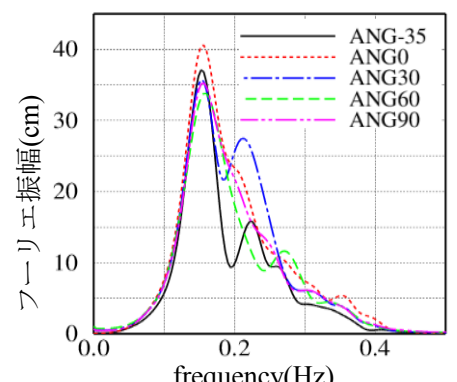

(c)フーリエ振幅スペクトル

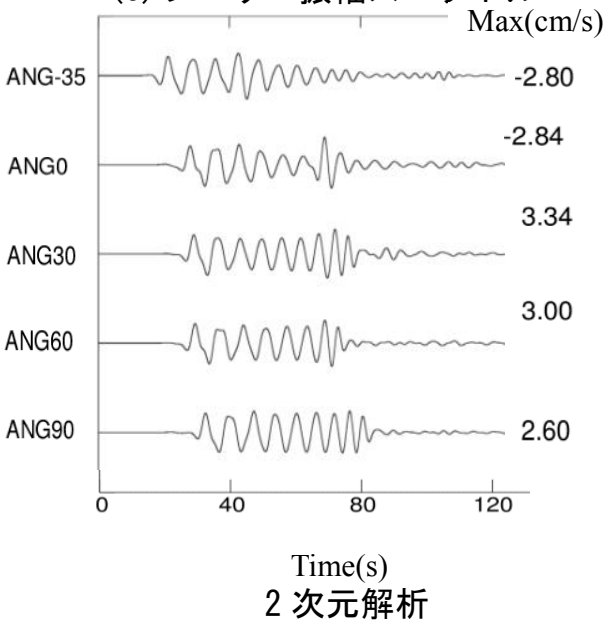

2 次元解析

(b) 時刻歴波形

図9 B-SKSにおける入射方向の差異がもたらす地盤応答への影響 


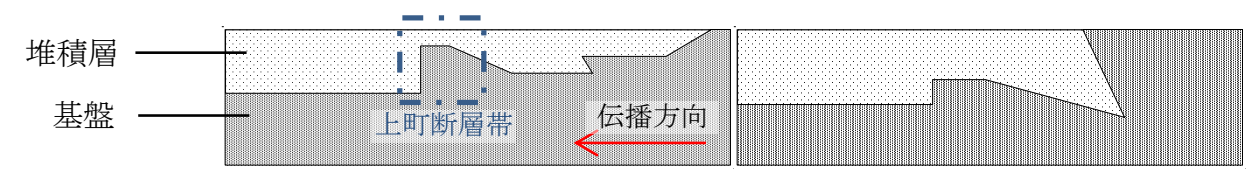

(a) ANG-35

(b) ANGO

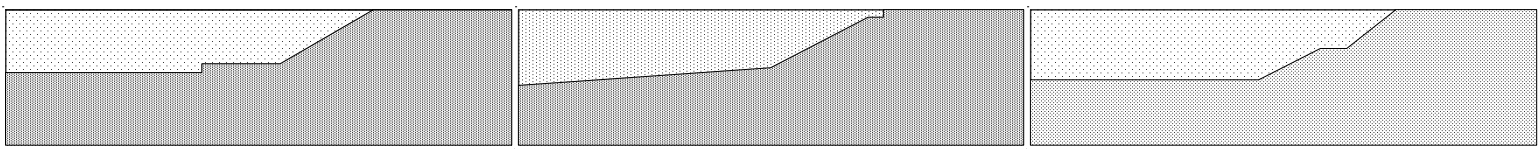

(c) ANG30

(d) ANG60

(e) ANG90

図10 各入射方向におけるB-SKSを通る測線上の2次元地盤断面の略図

\section{4. 上町断層帯の基盤形状が地盤応答に与える影響}

前章で挙げた上町断層帯の基盤形状が大阪湾沿岸部の地盤応答に与える影響を確認するため、図 1 に 示す入射方向を考慮した時の上町断層带の地盤構造を改変し、3次元解析を行う。3章で述べた通り、 図11(a)に示寸範囲で基盤が隆起しており、上町断層帯で大きな地中段差がある。この基盤形状を図11(a) に示寸範囲内で図11(b)、(c)の2パターンで断層部分の基盤隆起を無くすように改変し、地盤応答および 波動伝播特性に与える影響を調べた。図11(b)はB-SKSを通る基盤段差のみを改変した断面の略図であ る。図11(c)は基盤形状と基盤の隆起に伴う堆積層厚さの両者を改変した略図である。この2ケースにつ いて、図7と共通の地点における地盤応答を、前章までと同様の手法によって解析した。モデル領域、 減衰領域、各層の物性值等の諸条件は2章での検討と同一である。

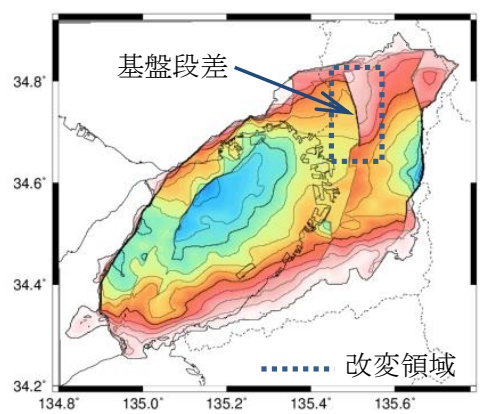

(a)地盤構造を改変する対象領域

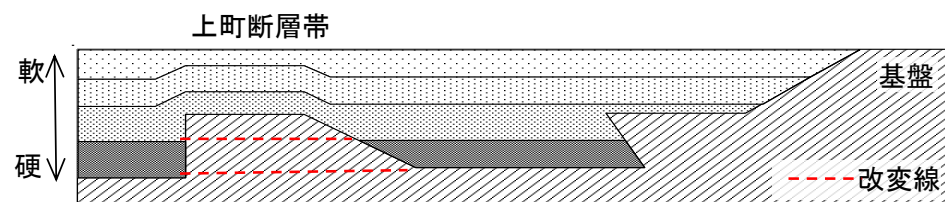

（b） case1 (基盤段差改変)

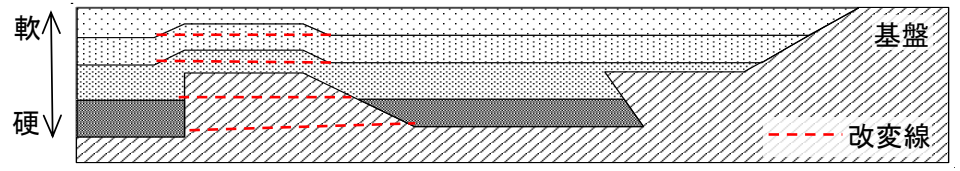

（c） case2 (基盤段差+断層改変)

図11地盤構造を改変する領域と地盤断面略図、及び各caselにおける地盤構造の改変状況

中心周期6秒のRicker波水平入射時の時刻歴波形を図12に示す。改変なしのときに比べ、 case 1 及び case2はB-SKSにおいていずれも上町断層帯より沿岸部側の地点にて後続波の影響が大きくなり、振幅 レベルが増加傾向にある。case1及びオリジナルのケースは、上町断層帯手前で一度地盤応答が小さく なり、沿岸部側で再度振幅が大きくなる傾向を示す。一方で、case2は岩盤側から沿岸部側に波動が大 きく減衰せず伝播している様子がわかる。この傾向については、後続波についても同様であり、振幅 レベルについてはcase $2 か ゙$ 最も大きくなった。以上より、大阪平野内の地盤増幅及び波動伝播特性は、 基盤および堆積層の形状によって影響されると判断できる。 


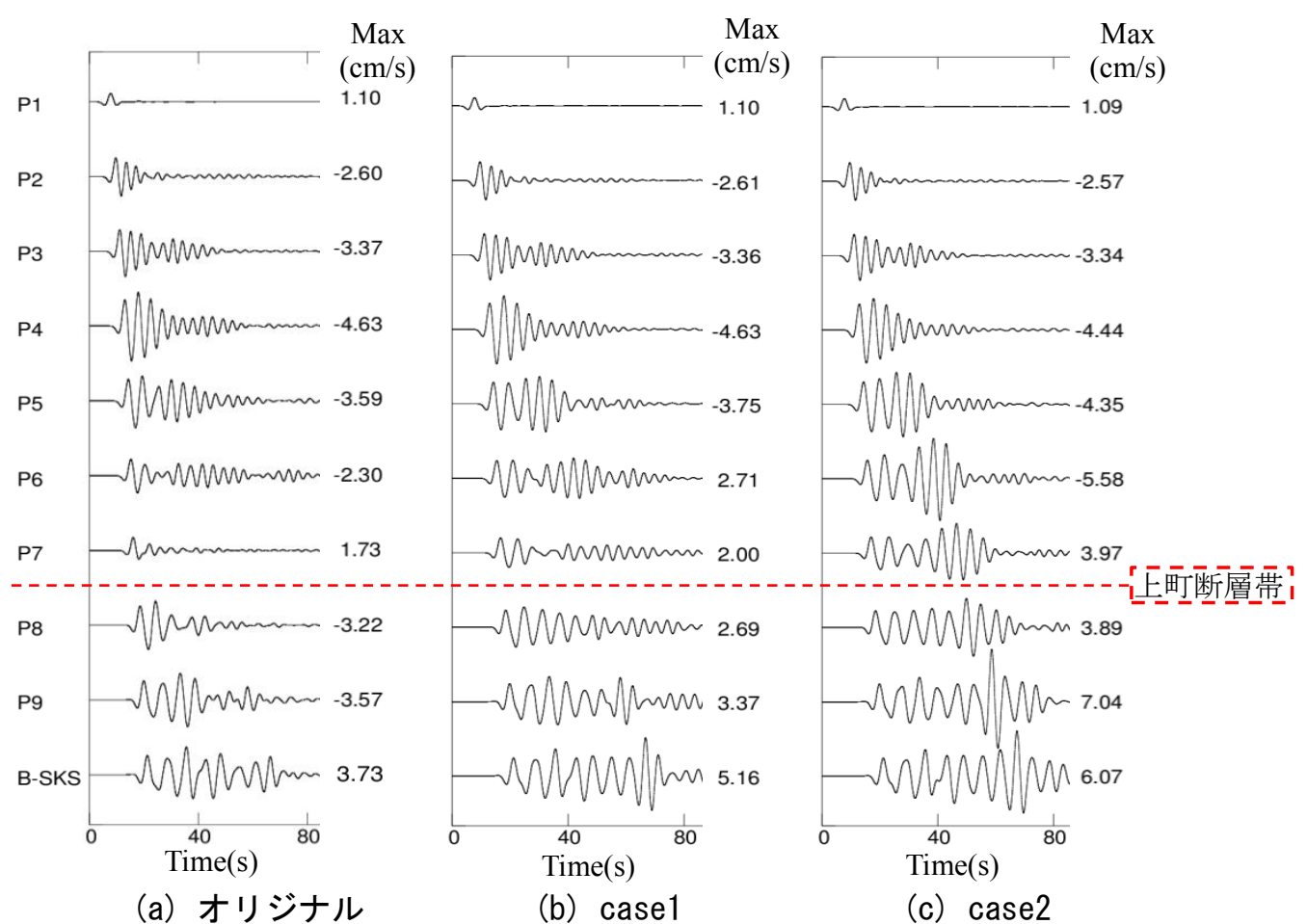

(a) オリジナル

(b) case 1

(c) case2

図12 中心周期6秒Ricker波入射時の時刻歴波形

case2 における表面波の干涉を確認寸るため、2.3 と同様に 2 次元解析を行い、3 次元解析の結果と比 較した。解析する地点は図 6 と共通である。2 次元解析と 3 次元解析における時刻歴波形の比較を図 13 に示す。岩盤側の波形に両者の間で顕著な差は確認できないが、上町断層帯付近の P6 から B-SKS では 2 次元解析に比べ 3 次元解析の後続波が増幅傾向にあった。これは、3 次元地形効果によって、2.3 と同様に B-SKS 付近で表面波が干涉するためと評価できる。

以上の結果から、大阪平野内の波動伝播特性は上町断層帯の基盤形状と基盤の隆起に、地盤増幅特 性は堆積層内で励起された表面波の干渉によってそれぞれ影響されることが検証された。また、3章で 述べた南海トラフ地震発生時の地震波入射方向における地盤応答が 3.11 本震時に比べ増加傾向を示す 要因は、本章で得られた上町断層帯がもたらす影響によって説明できる。

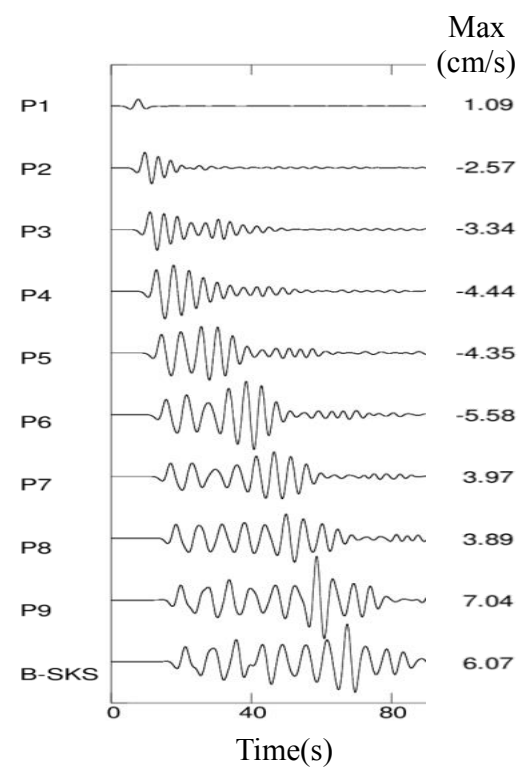

(a) 3次元解析

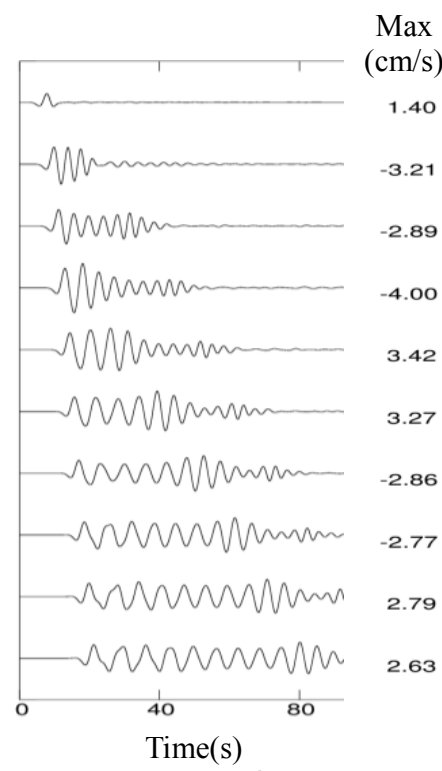

(b) 2次元解析

図13 case2における2次元解析と3次元解析の時刻歴波形の比較 


\section{5. まとめ}

3.11本震時、大阪湾沿岸部において長周期地震動による急激な地盤増幅が観測された。この地域にお ける地盤増幅特性の把握及び原因を究明するため、大阪平野を含む領域を対象に、水平SH波入射によ る波動伝播解析と 3.11 本震時の強震記録の再現解析を実施した。その結果、3.11本震時の応答波形、及 び地盤増幅傾向を概ね良好に再現でき、B-SKSでは周期7秒付近の成分が卓越する地震応答が再現され た。次に、3次元地盤構造が大阪湾沿岸部の地盤増幅特性と波動伝播特性に与える影響を把握するため、 地震波入射方向を想定される南海トラフ地震発生時の方向に設定し、地盤応答解析を行った。さらに、 3.11本震時の入射方向における、上町断層帯における基盤隆起を含む地盤構造を改変した場合の地盤増 幅特性、及び波動伝播特性について評価した。その結果、南海トラフ地震を想定した場合の大阪湾沿 岸部の地盤応答は、3.11本震時に比べ増加し、上町断層帯の基盤形状と基盤の隆起が波動伝播に影響す ることが把握できた。いずれの条件下においても2次元解析に比べ3次元解析の地盤応答が増大傾向に あったことから、堆積層内で励起された表面波が3次元地形効果によって干渉し、局所的な地盤増幅を 招くことが検証できた。上町断層帯の基盤段差による影響が比較的少ない東海・東南海沖に震源域を 想定した場合、大阪湾沿岸部の長周期地震動による地盤応答は、3.11本震時に比べ、より大きくなる可 能性が危惧される。

\section{謝 辞}

本研究では、防災科学技術研究所(K-NET、KiK-net)、気象庁(JMA)、建築研究所(BRI)、関西地震観 測研究協議会 $(\mathrm{CEORKA}) 、$ 都市再生機構+鴻池組 $(\mathrm{RC}-\mathrm{M} 、 \mathrm{~N})$ の強震記録を利用させていただきした。ま た、3次元地盤構造を作成するにあたり、大阪平野を含む領域の3次元地盤速度データを、大阪府にご 提供いただきました。ここに記して御礼申し上げます。

\section{参考文献}

1) 気象庁：東北地方太平洋沖地震における長周期地震動による摇れの実態に関する調査結果、2011年 http://www.data.jma.go.jp/svd/eqev/data/study-panel/tyoshuki_kentokai/kentokai1/siryou1.pdf (2015年09月 7 日).

2) 永野正行 ・上林宏敏 : 東北地方太平洋沖地震時の大阪平野内の長周期地震動特性と東西断面の地盤 増幅に着目したシミュレーション解析、2013年日本建築学会大会梗概集、2013年8月、pp.191-192.

3) Sato, K., Asano, K., Iwata, T. : Long-period Ground Motion Characteristics of the Osaka Sedimentary Basin during the 2011 Great Tohoku Earthquake, The 15th World Conference on Earthquake Engineering, Lisbon, Portugal, 2012.9.

4) 後藤賢人・永野正行 : 3次元差分法による東北地方太平洋沖地震時の大阪平野における長周期地震動 の再現解析、2013年日本建築学会大会梗概集、2013年8月、pp.189-190.

5) 酒井翔平・宮本裕司：2011年東北地方太平洋沖地震の大阪平野における地震動シミュレーション、 2013年日本建築学会大会梗概集、2013年8年、pp.193-194.

6) Yoshimura, C., Yamamoto, Y. and Hisada, Y. : Long-period ground motion simulation of 2004 off the Kii peninsula earthquakes and prediction of futureM8 class earthquakes along Nankai trough subduction zone, south of Japan island, The 14th World Conference on Earthquake Engineering, Beijing, China, 2008.10.

7) Yamada, N. and Iwata, T. : Long-period ground motion simulation in the Kinki area during the MJ 7.1 foreshock of the 2004 off the Kii peninsula earthquakes, Earth Planets Space, Vol.57 (No.3), 2005 , pp.197-202.

8) 吉村智昭・山本優 : 関東・濃尾・大阪平野を考慮した南海トラフ沿い巨大地震の長周期地震動シミ ユレーション、(その2 )想定東海・東南海連動地震のシミュレーション、2009年日本建築学会大会梗 概集、2009年8月、pp.93-94.

9) 天藤潤一・永野正行: 東北地方太平洋沖地震時の大阪平野沿岸部における長周期地震動増幅の成因、 2013日本地震工学会大会梗概集、2013年10月、pp.191-192.

10) 大阪府 : 平成16年度地震関係基礎調査交付金 大阪平野の地下構造調査、2006年.

11) 永野正行：グリッド間隔と時間刻みを可変とする3次元差分法を用いた2000年鳥取県西部地震時の 神戸地域における強震動評価、日本地震学会構造系論文集、第580号、2004年6月、pp.43-50.

12) 地震調査研究推進本部：長周期地震動予測地図2012年試作版、2012年 http://www.jishin.go.jp/main/chousa/12_choshuki/dat/nankai/lp2012nankai_str_val.pdf (2015年09月7日). 
13) 中央防災会議：南海トラフ巨大地震対策について、防災対策推進検討会、2013 年 http://www.bousai.go.jp/jishin/nankai/taisaku/pdf/20120829_2nd_report05.pdf(2015年09月7日).

\title{
Amplification Characteristics of Long-period Ground Motions in
}

\author{
Coastal Area of Osaka Bay and Effects of Seismic Wave Incident Direction \\ and 3D Geological Condition of Uemachi Fault belts
}

\author{
TENDO Jun-ichi ${ }^{\text {1) }}$, NAGANO Masayuki ${ }^{2)}$ and UEBAYASHI Hirotoshi ${ }^{3)}$ \\ 1) Graduate Student, Tokyo Univ. of Science \\ 2) Tokyo Univ. of Science, Dr. Eng. \\ 3) Kyoto Univ. Research Reactor Institute, Dr. Eng.
}

\begin{abstract}
During the 2011 off the Pacific coast of Tohoku Earthquake, long-period ground motions were largely amplified in coastal area of the Osaka Bay, resulting in the large drift at the top of Osaka Prefectural Government Sakishima Building. Amplification characteristics of the long period ground motions are investigated for the 3-D geological model of the Osaka Plain subjected to the horizontally incident SH wave using the 3-D finite difference method. Synthetic waves in the Osaka Plain including the Bay area were in good agreement with the observed ground motions. The ground motions in the Osaka Bay area were amplified mainly by 3-D geological condition as the focusing effect of travelling waves.
\end{abstract}

Keywords: The 2011 off the Pacific coast of Tohoku Earthquake, Coastal area of Osaka Bay, Long-period ground motion, Site amplification characteristics, 3-dimensional finite difference method, Uemachi fault belts 